\title{
REACTION OF COMMON BEAN LINES DERIVED FROM RECURRENT SELECTION FOR WHITE MOLD RESISTANCE AND AGGRESSIVENESS OF Sclerotinia sclerotirum ISOLATES
}

\author{
REAÇÃO DE LINHAGENS DE FEIJÃO COMUM DERIVADAS DE SELEÇÃO \\ RECORRENTE PARA RESISTENNCIA AO MOFO BRANCO E AGRESSIVIDADE DE \\ ISOLADOS DE Sclerotinia sclerotiorum
}

\author{
Monik Evelin LEITE ${ }^{1}$; Izabel Cristina Rodrigues de FIGUEIREDO ${ }^{2}$; Juliana Andrade DIAS ${ }^{3}$; \\ Filipe Couto ALVES ${ }^{4}$; João Bosco dos SANTOS ${ }^{3}$ \\ 1. Department of Agriculture, Federal University of Lavras, Lavras, MG, Brazil; 2. Plantar S/A - Unit Wood Preservation, Farm Buenos \\ Aires II, Curvelo, MG, Brazil; 3. Department of Biology, Federal University of Lavras, Lavras, MG, Brazil. jbsantos@ dbi.ufla.br; 4. \\ Department of Genetics, Agriculture College "Luiz de Queiroz", University of São Paulo, Piracicaba, SP, Brazil.
}

\begin{abstract}
The objectives of this study were to verify the resistance of common bean lines derived from recurrent selection for white mold resistance and to identify those more stable to different isolates; to compare the aggressiveness of different Sclerotinia sclerotiorum isolates; and to verify isolates x lines interaction. Fifteen common bean lines were evaluated, twelve derived from recurrent selection for white mold resistance, one non-adapted source of resistance (Cornell 605), one moderately resistant and adapted (VC-16) and one susceptible to white mold (Corujinha). Ten isolates were used to inoculate the common bean lines through the straw test. A total of ten experiments were performed, one for each isolate. The randomized complete block design with three replications was used in each experiment. Each plot had five plants inoculated in two main branches, therefore the plot data was the average of the ten evaluations through a scale of nine grades. Diallel analysis were used to estimate the general reaction capacity (lines) and general aggressiveness capacity (isolates) to measure the resistance to white mold and the aggressiveness of the isolates, respectively. The GGE biplot analysis was used to group the common bean lines based on their resistance alleles and identify those more instable to the isolates. The resistance of the lines P4 and P10 was similar to Cornell 605, and they had stable reaction to different isolates and "Carioca" grain type. The lines of the advanced cycles of recurrent selection accumulated more favorable alleles than those of the first cycles, confirming the efficiency of the recurrent selection to increase white mold resistance in common bean. In addition, it was identified more aggressive isolates, UFLA 109 and UFLA 116, and a small magnitude of isolates $\mathrm{x}$ lines interaction, indicating a predominance of the horizontal resistance of the lines
\end{abstract}

KEYWORDS: Phaseolus vulgaris. Physiological resistance. Line x isolate interaction. Straw test.

\section{INTRODUCTION}

White mold caused by Sclerotinia sclerotiorum (Lib.) de Bary is a yield-limiting disease of common bean (Phaseolus vulgaris L.) in Brazil. Crop losses due to white mold outbreaks in beans are in average $30 \%$, but can reach $100 \%$ under favorable climatic conditions to disease development (SCHWARTZ; SINGH, 2013).

Among the methods for white mold control, genetic resistance is the most indicated. However, the level of resistance to white mold in commercial common bean cultivars is considered low especially those of Mesoamerican origin (SCHWARTZ; SINGH, 2013). High levels of resistance are only found in the secondary genetic pools such as Phaseolus coccineus and Phaseolus costaricensis (SINGH et al., 2009; MIKLAS et al., 2006; SCHWARTZ; SINGH, 2013). Therefore, some researchers have been working to increase the level of white mold resistance in common bean cultivars
(LYON et al. 1987; TERÁN; SINGH, 2009; TERÁN; SINGH, 2010; LEITE et al., 2016). It has already been identified lines with similar resistance to non-adapted sources in Brazil (GONÇALVES; SANTOS, 2010; LEITE et al., 2016; SILVA et al., 2014).

The difficulty in obtaining resistant cultivars to white mold is related to the genetic control of the resistance, which is complex with various genes, mainly the horizontal resistance. This type of resistance involves mechanisms related to physiological resistance and escape mechanism (SCHWARTZ; SINGH, 2013). Among genes that provide physiological resistance, specific genes and others with general effects tend to minimize the damage caused by the pathogen and/or make difficult the advancement of the pathogen in the plant tissue (JOHAL et al., 1995). Genes participating in the physiological resistance to white mold were also related to the metabolic pathway of lignin, phenolic compounds, and compounds related 
to the metabolism of reactive species of oxygen (YANG et al., 2007; LEITE et al., 2014). According to Yang et al. (2007), more than 300 genes change their expression in the presence of the pathogen; therefore, various genes control physiological resistance. It has already been identified more than 27 QTL related to physiological resistance and 36 related to escape mechanism in common bean (MIKLAS et al., 1013; PÉREZ-VEJA et al., 2012; LARA et al., 2014; LARA et al., 2015). This complexity of white mold resistance may difficult the success in the selection. So, to accumulate favorable alleles, recurrent selection is a method that has been efficient in common bean for several characters, including white mold resistance (LEITE et al., 2016; LYON et al., 1987; TERÁN; SINGH, 2010).

In addition to the complexity of the white mold resistance, wide variability of $S$. sclerotiorum isolates make difficult the selection of resistant genotypes (CARNEIRO et al., 2011; PASCUAL et al., 2010; SCHWARTZ and SINGH, 2013; SILVA et al., 2014). Although, some papers report a small variability of this pathogen in Brazil (LEHNER et al., 2015; LEHNER et al., 2016 a).

During the selection of lines with high levels of resistance, a single isolate was frequently used by most of the authors. Nevertheless, the resistance of lines should be confirmed assessing different isolates. The resistance of lines can be not discriminated or a false resistance can be indicated when isolates with low aggressiveness are used. Those S. sclerotiorum isolates more aggressive are more efficient for identifying the most resistant lines (SILVA et al., 2014).

In this context, the goals of this study were to verify the resistance of common bean lines derived from recurrent selection for white mold resistance; to identify those more resistant and stable against different isolates; to compare the aggressiveness of different $S$. sclerotiorum isolates; and to verify isolates $x$ lines interaction using GGE (genotype main effect plus genotype-byenvironment interaction) biplot and diallel analyses.

\section{MATERIAL AND METHODS}

Fifteen common bean lines were evaluated (Table 1). Twelve of them were derived from recurrent selection for white mold physiological resistance, and adapted to Southeastern Brazil (LEITE et al., 2016). Three controls were used: one partially resistant line not adapted to the South region of Minas Gerais State (Cornell 605) identified by Griffiths (2009); one susceptible line adapted to that region (Corujinha) (SILVA et al., 2014); and one elite line with low resistance to white mold (VC16) comparing to Corujinha.

Table 1. Isolates of S. sclerotiorum, its respective geographic origin and lines derived from different cycle of recurrent selection plus three controls.

\begin{tabular}{lllllllll}
\hline Isolates & Isolate Code & Origen & Lines & Name & Cycle & Lines & Name & Cycle \\
\hline I1 & UFLA 118 & Lambari - AT & P1 & $46 x 37 / 7$ & CIII & P11 & C6-54/4 & CVI \\
I2 & UFLA 109 & Lambari -AT & P2 & $47 x 43 / 10$ & CIII & P12 & C6-60/12 & CVI \\
I3 & UFLA 40 & Conquista - T & P3 & 72/18-J & CVII & P13 & Cornell 605 & - \\
I4 & UFLA 3 & Ijaci - AT & P4 & 84/6-J & CVII & P14 & Corujinha & - \\
I5 & UFLA 27 & Lambari - AT & P5 & C1-32/7 & CI & P15 & VC16 & - \\
I6 & UFLA 116 & Lambari - AT & P6 & C2-46/5 & CII & & & \\
I7 & UFLA 65 & Unaí - T & P7 & C5-24/10 & CV & & & \\
I8 & UFLA 124 & Lambari - AT & P8 & C6-14/7 & CVI & & & \\
I9 & UFLA 43 & Coimbra - AT & P9 & C6-50/3 & CVI & & & \\
I10 & UFLA 31 & Lambari - AT & P10 & C6-50/5 & CVI & & & \\
\hline AT - altitude tropical weather & - - T tropical weather & & & & &
\end{tabular}

Eight seeds of each line were sown in 3.5 liter pot containing the substrate composed of three: one: one, soil: sand: manure, respectively. All the fifteen lines were evaluated in ten experiments using a completely randomized design (CRD) with three replications. Each experimental unit was a pot containing five plants and each plant was inoculated in two main branches by cutting off the upper part of each, at $2,5 \mathrm{~cm}$ from the node, and placed a micropipette tip with the inoculum. In each 
Reaction of common bean...

experiment, the lines were evaluated using a different isolate. All experiments were carried out in a greenhouse in the same time. The plants were irrigated periodically and fertilized according to the recommendations for the crop.

Ten isolates of $S$. sclerotiorum used in inoculations were collected at different locations of the State of Minas Gerais. They were obtained from the mycology collection of the laboratory of disease resistance DBI/UFLA (Table 1).

The sclerotia were surface disinfected by immersing in $70 \%$ ethanol for one minute, one percent sodium hypochlorite solution for three minutes and three times in deionized and sterilized water. Then, the fungus was chopped up in Petri dishes containing potato, dextrose and agar (PDA) with chloramphenicol $\left(1 \mu \mathrm{L} \mathrm{mL}^{-1}\right)$ and incubated in BOD at $22^{\circ} \mathrm{C}$ for three days. Next, the mycelialmedium disc was transferred to new Petri dish with PDA to achieve higher uniformity. Dishes fully covered with mycelium were used to prepare the inoculum for posterior inoculation of plants.

The isolates were inoculated by the straw test method 28 days after emergence of the plants according to Terán and Singh (2008). Seven days after the inoculation, plants were evaluated using the diagrammatic scale of one (absence of symptom) to nine (death of the plant) according to Terán and Singh (2009).

The data were tested to check the assumptions of ANOVA and they were met. The mean score of the disease per plot was subjected to analysis of variance and Scott Knott (1974) mean clustering test. The diallel analysis was performed according to the methodology proposed by Melo and Santos (1999) with the following model:
LEITE, M. E. et al.

$$
Y i j=\mu+r_{i}+\alpha_{j}+s_{i j}+e_{i j} \text {. }
$$

Where $Y_{i j}=$ severity of disease exhibited by line $i$ when inoculated with isolate $j ; r_{i}=$ fixed effect of horizontal resistance of line $i ; \alpha_{j}=$ fixed effect of the aggressiveness of isolate $j ; \mathrm{s}_{\mathrm{ij}}=$ fixed effect of vertical resistance of line $i$ inoculated with isolate $j$; and $\mathrm{e}_{\mathrm{ij}}=$ experimental error associated with observation $Y_{i j}$. The estimates of the general reaction capacity (GRC) of each line, of the general aggressiveness capacity (GAC) of each isolate, and of the specific line $\mathrm{x}$ isolate interaction capacity (SIC), were calculated using the Genes software (CRUZ, 2013). GGE biplot analysis was used to group the common bean lines based on their resistance alleles, identify those more instable to the isolates of S. sclerotiorum, and estimate the isolateby-line interaction component by mean GGE biplot software (YAN; KANG, 2003). This procedure uses principal component analysis and its information may complement the diallel analysis.

\section{RESULTS AND DISCUSSION}

The experiments were conducted with good precision, that is low coefficient of variation (CV) and moderate to high selective accuracy (Table 2). The accuracy was lower in experiments with the I4, I8 and I5 isolates; the I4 and I8 isolates were less aggressive with lower means, and statistic difference was not found among lines for I5 at 5\% significance level. Therefore, these isolates are not efficient to discriminate the reactions of the lines. The mean aggressiveness of each isolate on all lines and the mean reaction of each line to all isolates were also estimated (Table 2).

Table 2. Estimates of mean aggressiveness value of isolates (MI), mean reaction value of the lines (ML), mean square (MS) of the lines based on reactions to each isolate of $S$. sclerotiorum, selective accuracy $\left(\mathrm{r}_{\mathrm{g}}\right)$ and coefficient of variation $(\mathrm{CV})$.

\begin{tabular}{lllllllll}
\hline Isolates $^{3}$ & $\mathbf{M I}^{\mathbf{2}}$ & $\mathbf{M S}^{\mathbf{1}}$ & $\mathbf{C V}(\boldsymbol{\%})$ & $\mathbf{r}_{\mathrm{gg}}(\boldsymbol{\%})$ & Lines $^{\mathbf{3}}$ & $\mathbf{M L}^{\mathbf{2}}$ & Lines $^{\mathbf{3}}$ & ML $^{\mathbf{2}}$ \\
\hline I1 & $5.37 \mathrm{c}$ & $2.654^{* *}$ & 15.58 & 85.88 & $\mathbf{P 1}$ & $5.67 \mathrm{~b}$ & $\mathbf{P 1 1}$ & $4.57 \mathrm{c}$ \\
$\mathbf{I 2}$ & $5.96 \mathrm{a}$ & $1.727^{*}$ & 13.65 & 78.16 & $\mathbf{P 2}$ & $4.54 \mathrm{c}$ & $\mathbf{P 1 2}$ & $4.75 \mathrm{c}$ \\
$\mathbf{I 3}$ & $5.2 \mathrm{c}$ & $1.578^{* *}$ & 13.44 & 83.09 & $\mathbf{P 3}$ & $4.65 \mathrm{c}$ & $\mathbf{P 1 3}$ & $4.07 \mathrm{~d}$ \\
$\mathbf{I 4}$ & $3.43 \mathrm{e}$ & $0.907^{*}$ & 18.68 & 73.99 & $\mathbf{P 4}$ & $4.26 \mathrm{~d}$ & $\mathbf{P 1 4}$ & $6.23 \mathrm{a}$ \\
$\mathbf{I 5}$ & $3.93 \mathrm{~d}$ & $0.242^{\mathrm{NS}}$ & 9.36 & 66.43 & $\mathbf{P 5}$ & $5.31 \mathrm{~b}$ & $\mathbf{P 1 5}$ & $5.59 \mathrm{~b}$ \\
$\mathbf{I 6}$ & $5.91 \mathrm{a}$ & $2.586^{* *}$ & 10.68 & 91.96 & $\mathbf{P 6}$ & $5.71 \mathrm{~b}$ & & \\
$\mathbf{I 7}$ & $4.97 \mathrm{c}$ & $1.689 * *$ & 12.02 & 88.80 & $\mathbf{P 7}$ & $4.63 \mathrm{c}$ & & \\
$\mathbf{I 8}$ & $3.6 \mathrm{e}$ & $1.882^{* *}$ & 18.72 & 87.48 & $\mathbf{P 8}$ & $4.58 \mathrm{c}$ & & \\
$\mathbf{I 9}$ & $5.16 \mathrm{c}$ & $1.868^{* *}$ & 13.93 & 85.03 & $\mathbf{P 9}$ & $4.72 \mathrm{c}$ & & \\
$\mathbf{I 1 0}$ & $5.59 \mathrm{~b}$ & $3.312^{* *}$ & 12.34 & 92.55 & $\mathbf{P 1 0}$ & $4.39 \mathrm{~d}$ & & \\
\hline
\end{tabular}

$1 *$ and $* *$, significant, respectively at $5 \%$ and $1 \%$ of probability using $\mathrm{F}$ test; ${ }^{2}$ mean value followed by different letters is genetically heterogeneous according to the test of Scott-Knott (1974) with $5 \%$ probability. ${ }^{3}$ The names of the lines and isolates are in Table 1. 
The wide variability of reactions of the lines to isolates and of the aggressiveness of isolates (Table 2), indicates we can estimate the magnitude of resistance of each line through the general reaction capacity (GRC) and the magnitude of aggressiveness of each isolate through the general aggressiveness capacity (GAC) using diallel analysis. Both GRC and GAC were different statistically $(p<0.0001)$. This might indicates an important participation of the additive genetic effects in the control of white mold resistance of the common bean lines and in the aggressiveness of the isolates of $S$. sclerotiorum (Figure 1).

Lower estimates of GRC and means of reaction were verified in the resistant control Cornell 605 (P13), line P4 selected in the cycle VII and P10 from cycle VI. This indicates the higher horizontal resistance of the lines with lower
LEITE, M. E. et al.

proportion of tissue lesion, once the resistance in these lines was more constant, not depending of isolate used. The level of resistance of these two lines has been reported as similar to Cornell 605 and A195 sources and superior of other well-known sources of resistance, such as G122 and Ex-Rico-23 (LEITE et al., 2016). The lines P2, P3, P4, P7, P8, P9, P10, P11, and P12 also exhibited some level of resistance. However, other lines considered by authors with higher resistance (P1 and P6) had lower resistance level in this study (Figure 1a and table 1). Leite et al. (2016) selected lines using only one isolate and here we used ten different isolates, once the response of white mold resistant genotypes may vary depending on the isolate used and environment evaluated (LEHNER et al., 2016b; OTTO-HANSON et al., 2011).

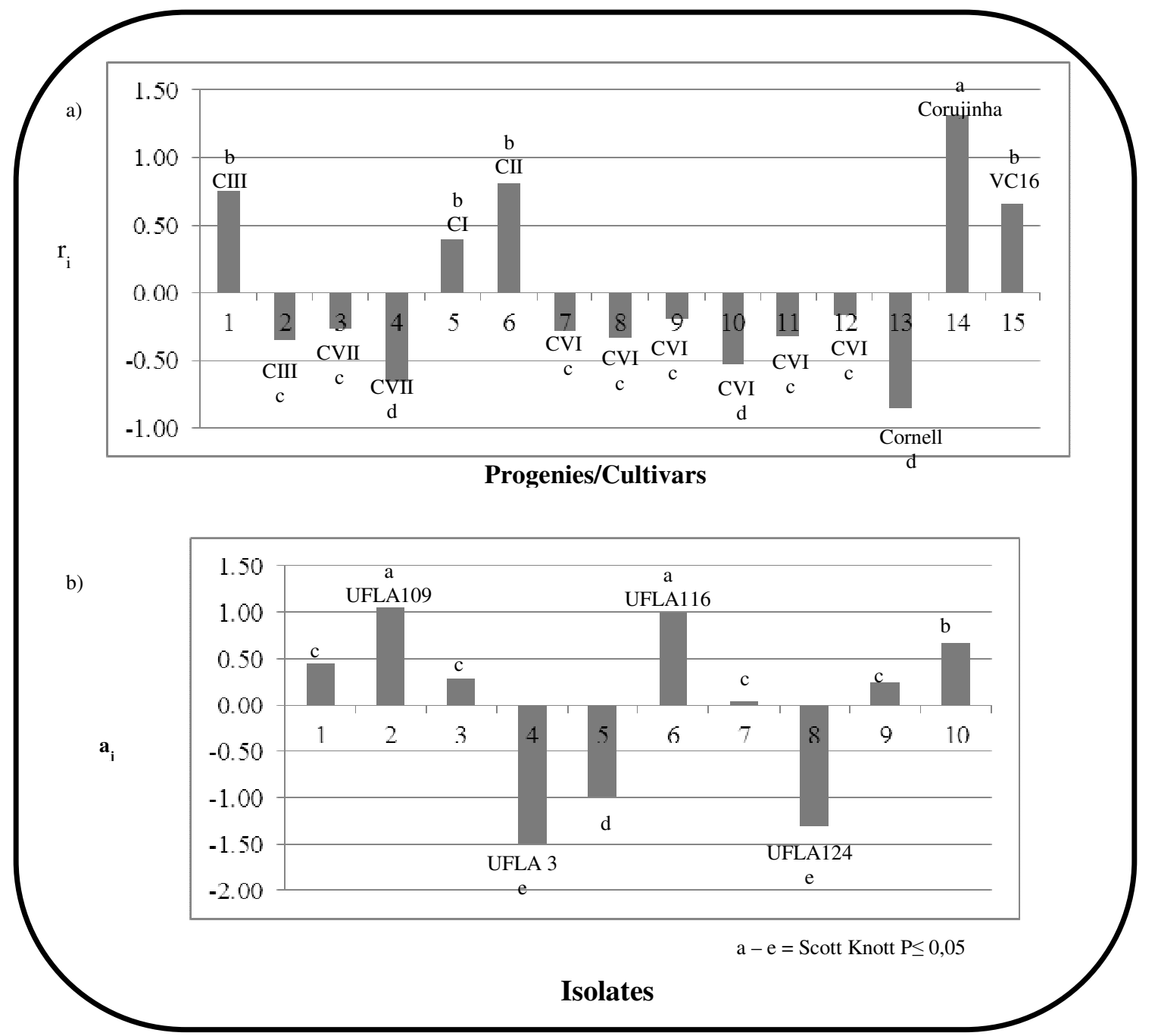

Figure 1. (a) Magnitude of genetic effect of resistance $\left(r_{i}\right)$ of common bean lines (P1-P15) to different isolates of $S$. sclerotiorum (14=P14=Corujinha susceptible control; 13=P13= Cornell 605 resistant control); (b) magnitude of genetic effect of aggressiveness $\left(a_{j}\right)$ of isolates (1-10) of S. sclerotiorum inoculated on the common bean lines. Each letter indicated the magnitude of genetic effect according to the Scott-Knott (1974) grouping $(\mathrm{P}=0.05)$. 
In this study, the single resistance source used as control is the Cornell 605, considered the best resistance source with more stable resistance reaction, comparing with A195 and G122, in a study with eight different isolates (LEHNER et al., 2016b). The selection of the lines P4 and P10, similar to that source of resistance, was a result of the efficiency of recurrent selection in recombining resistant alleles from different sources of lower levels of resistance. Other lines with some resistance were also selected (Table 2 and Figure 1a), and all of them having upright plant that can contribute to higher resistance in the field (LEITE et al., 2016).

Graph analysis of principal components via GGE biplot also allowed verifying the high level of resistance of the control Cornell 605, lines P4 and P10 and verifies that the lines P1, P6 and P5 exhibited a low level of resistance to the isolates, as the elite line VC16 and the control P15. These results were similar to those obtained by diallel
LEITE, M. E. et al.

analysis, indicating that both methodologies used were equivalent. However, through GGE biplot the lines were grouped according the particular pattern of resistance to the isolates, the lines on the same quadrant (P13, P10, P2, and P8; lines P11, P7, and P3; lines P4 and P9; lines P12, P5, P15, and P6; and lines $\mathrm{P} 1$ and $\mathrm{P} 14)$ probably have similar resistance alleles according to Yan et al (2003) (Figure 2 a). So, the advantage to use GGE biplot is the possibility to separate the lines according the resistance pattern, allowing us infer about the group of alleles of them. The lines P10 and P4 exhibited similar resistance to Cornell 605 (P13), and they still exhibit stable resistant reaction to different isolates (Figure $2 \mathrm{~b}$ ). These two lines were grouped into separate clusters in the GGE biplot analysis, indicating these lines as having different group of favorable alleles, related to white mold resistance. Therefore, they can be intercrossed to increase the resistance level in a breeding program.

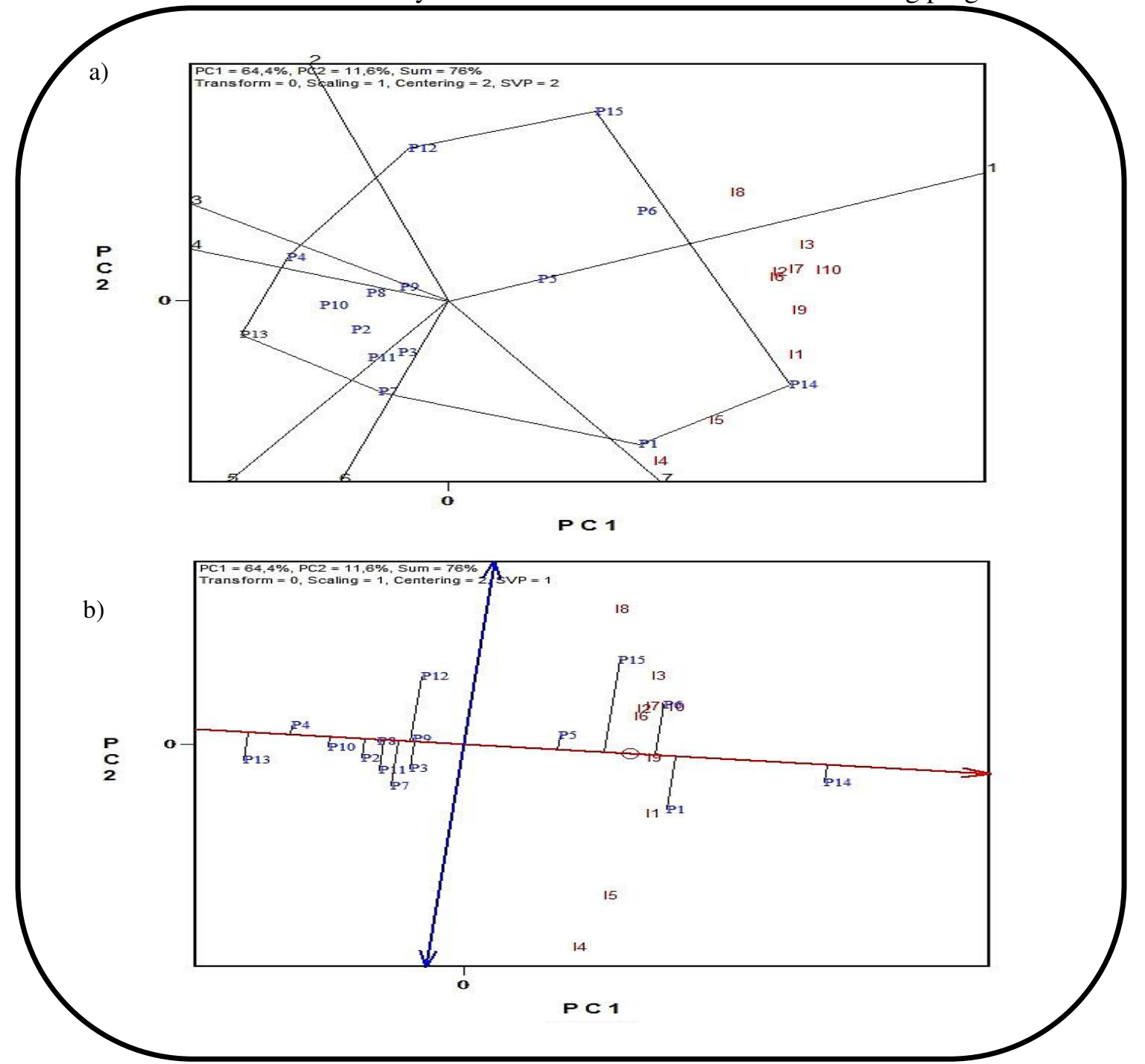

Figure 2. (a) GGE biplot based on the reaction of 15 lines of common bean (identified by letter P) to 10 isolates of $S$. sclerotiorum (identified by letter I); (b) stability of 15 common bean lines. Principal component $1(\mathrm{PC} 1)=$ $64 \%$, principal component $2(\mathrm{PC} 2)=12 \%$, they together explained $76 \%$ of the total variation. 
Although the cultivar Cornell 605 has exhibited a relative stability in this work as observed by Lehner et al. (2016b), it was unstable in the evaluation of Pascual et al. (2010), highlighting the importance of inoculating the line with various isolates. The lines P4 and P10 exhibited higher stability than Cornell 605 (P13) (Figure 2b), which can be due to their higher adaptability to environmental conditions in the region, once they were selected after inoculation in the field conditions (LEITE et al., 2016). These lines also have grain type "Carioca", one of the most consumed in Brazil. The great importance of these lines is because the most of the sources of white mold resistance are of Andean origin, not adapted to Southeastern Brazil and with grain different of commercial types (PASCUAL et al., 2010). Some lines and cultivars with moderate resistance and well adapted in different regions of Brazil were identified (GONÇALVES; SANTOS, 2010; SILVA et al., 2014), but the level of resistance of these lines was compared with sources with minor resistance than Cornell 605.

The most susceptible lines were derived from the first cycles of recurrent selection (CI, CII, and CIII), compared to the lines selected in advanced cycles of selection (Figure 1), confirming the efficiency of this procedure to increase the level of resistance to white mold. The lines exhibited different levels of resistance due to the occurrence of different alleles that were gradually accumulated through the process of recurrent selection (LEITE et al., 2016). The complexity of the bean resistance to white mold is showed by Miklas et al. (2013) who exhibited 27 QTLs related to the physiological resistance of common bean to white mold. Additionally, others QTLs have already been identified expressing in the Brazilian conditions (LARA et al., 2014; LARA et al., 2015).

Using the same lines of common bean, we noticed a high variability in the isolates aggressiveness, the mean reaction of the lines ranged from 3.4 to 6 depending of the inoculated isolate, and were obtained five groups by the procedure of Scott Knott (Table 2). These results were confirmed by heterogeneity of the genetic effect of the aggressiveness of each isolate, as shown in Figure 1b.The isolates I2 and I6 showed high general aggressiveness capacity (GAC) in the experiments because they caused higher lesion in evaluated common bean lines. The identification of isolates with high aggressiveness allowed a better discrimination of the host in relation to the level of resistance, as reported by Silva et al. (2014), and they are useful in routine selection activities. The isolates I4 and I8 were less aggressive and had less importance in discriminating common bean genotypes and they are not recommended for screening of lines for white mold resistance (YAN; FALK, 2002). The results for aggressiveness of the isolates using GGE were also similar (Figure 3). Isolates from the same group may share the same alleles of aggressiveness, and generate similar reactions when used for screening of different genotypes. The first two principal components explained $87 \%$ of the total phenotypic variation which give credibility of the results.

It is worth mentioning the great variability to the aggressiveness of different isolates of $S$. sclerotiorum, identified by Carneiro et al. (2011), Koga et al., (2014), Otto-Hanson et al. (2011), Pascual et al. (2010), and Silva et al. (2014). Some of them identified in Brazil (CARNEIRO et al., 2011; KOGA et al., 2014; SILVA et al., 2014). Similar aggressiveness among isolates from different cultivated areas of Southeast Brazil, have been identified by Lehner et al (2016a), although the authors have used only two common bean genotypes; however, small variation among isolates was observed in the more resistant A195 genotype, which probably induced the expression of different aggressiveness of the isolates.

Kull et al. (2004) identified four mycelial compatibility groups (MCGs) on the same site, and reported variable aggressiveness among groups. These authors also argued that agricultural regions have complex population structure and the emergence of new genotypes localized in single fields may be an indication of MCGs or clones adapted to specific field microclimates or hosts, and is less likely the result of genetic exchange and recombination. However, the authors Lehner et al (2015) identified low variability among isolates of Minas Gerais state, which may have been influenced by the collection area.

The isolate I5 (UFLA 27), identified as one of the less aggressive in this work, was also used by Silva et al. (2014), who identified it was the most aggressive. This isolate was evaluated by Silva et al. (2014) in experiments in 2011 and 2012. The same isolate was used in several experiments in successive cycles of recurrent selection, when there was evidence of loss of aggressiveness. Also Carneiro et al. (2011) evaluated isolates of $S$. sclerotiorum and the most aggressive (Goiânia 4) was one of the least aggressive in the research of Silva et al. (2014), again after used in several experiments (LEITE et al., 2016). This apparent reduction in aggressiveness is probably due to the 
constant isolate multiplication on artificial media, since it was identified as the most aggressive.

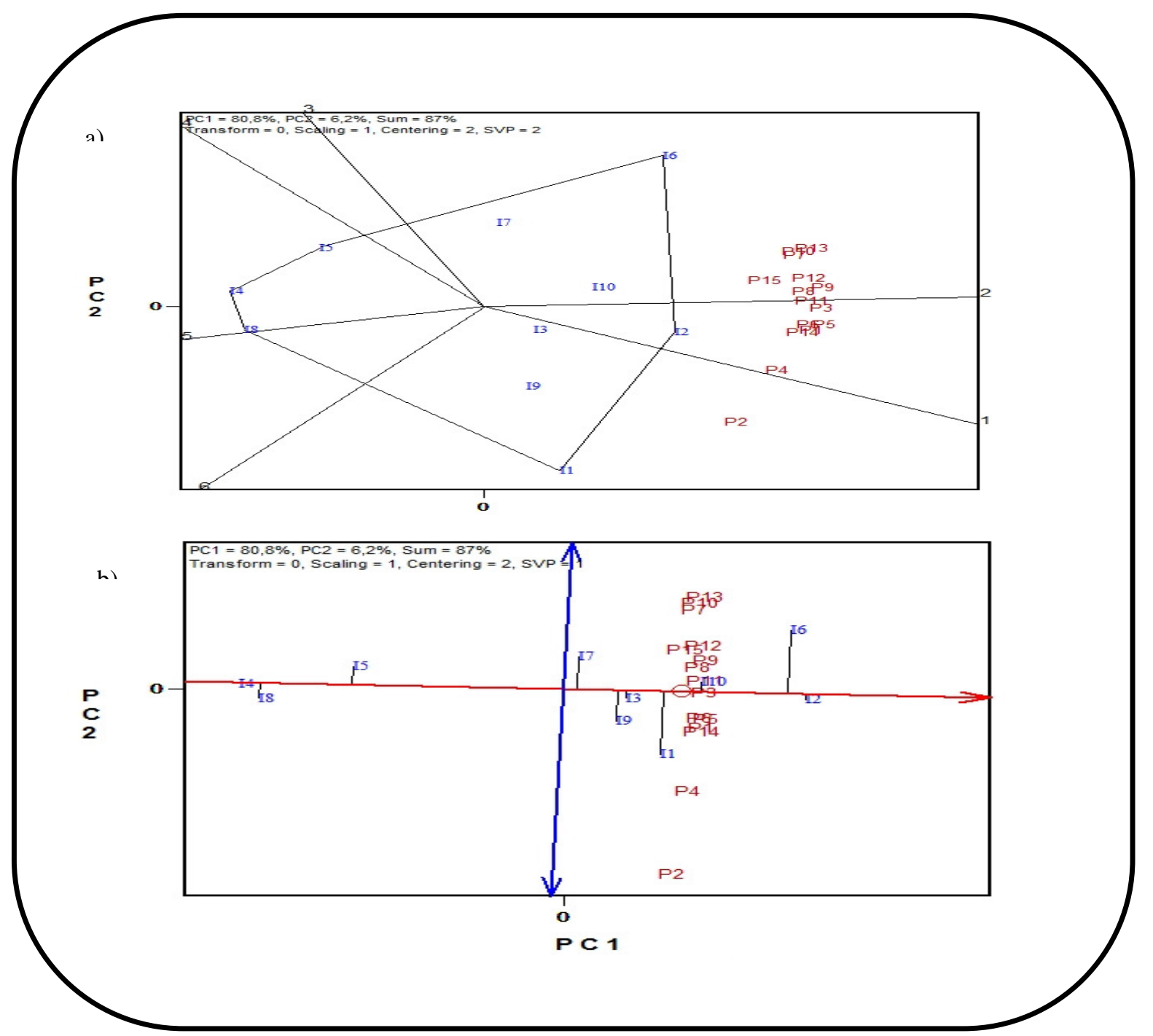

Figure 3. (a) GGE biplot based on the aggressiveness of isolates of S. sclerotiorum (identified by letter I) in 15 lines of common bean(identified by letter P) (b) stability of 10 isolates of S. sclerotiorum $(\mathrm{PC} 1=81 \%, \mathrm{PC} 2=6 \%$ corresponds $87 \%$ of total variation).

The aggressiveness of isolates have also been associated with their origin (LEHNER et al., 2013; OTTO-HANSON et al., 2011). Isolates from colder regions tend to be more aggressive than those from warmer regions, especially when the evaluations are performed in region with similar climatic conditions to the isolate origin (SILVA et al., 2014). In this research, the evaluations were performed in a region with altitude of $915 \mathrm{~m}$, which is considered a altitude tropical climate with mild temperatures, especially in the fall and winter. As we sought to identify more aggressive isolates, we prioritize those from places with milder climates and similar conditions to the region of the common bean lines evaluation and selection, although it was also used two isolates of tropical climate (I3 and I7).
These isolates showed intermediate aggressiveness, and those of tropical altitude climate exhibited varied behavior, some were more aggressive (I2, I6 and I10), and some were less aggressive (I4, I5 and I8). In this case, we could not associate the origin with aggressiveness.

Isolates from the same location showed quite varied aggressiveness, especially those derived from Lambari (Table 1 and Figures $1 \mathrm{~b}$ and $3 a$ ) probably because the isolate collection is derived from experimental areas, where assays used different lines and even annual crops of different species. Studies using DNA fingerprints and MCGs have shown that $S$. sclerotiorum populations show a higher variability on a local scale, where boundaries 
have been established by genetic or phylogenetic means (MALVÁREZ et al., 2007).

From the diallel analysis it was also estimated the specific reaction capacity (SRC), and they were different at first sight, indicating the possible participation of the vertical resistance in the control of this trait. However, even if the SRC is detected, its value is 15 times less than the GRC. This very small amount of specific reaction capacity is derived from the small interaction line $\mathrm{x}$ isolate. In this work, the interaction occurred specially for 4 out of 15 lines investigated (P15, P12, P1 e P6), and most of them was relatively stable (Figure $2 b$ ). Regarding the contribution of each isolate for the interaction, the I6 and I1 contributed more, followed by I7 and I9. The isolates I2, I10, I3, and I4 were the most stable, the I 2 was also the most aggressive, and they contributed less for interaction (Figure 3b).

According to Parlevliet (1981), a small line $\mathrm{x}$ isolate interaction did not imply the occurrence of vertical resistance, once similar results are common in the system of host $\mathrm{x}$ pathogen interaction, where only horizontal resistance has occurred. Actually, such interaction is probably related to the variation in aggressiveness of isolates derived from different environments, especially regarding temperature
(LEHNER, et al. 2013; SILVA et al, 2014). Indeed, the result is typical of horizontal resistance, as observed by Melo and Santos (1999), even using simulation data. Different authors also identified small isolate $\mathrm{x}$ line interaction in similar plant $\mathrm{x}$ pathogen system (PARLEVLIET, 1981; PASCUAL et al. 2010; SILVA et al. 2014).

Pascual et al. (2010) also verified three genotypes that contributed most to the interaction and claimed that such genotypes will be useful for the characterization of isolates of $S$. sclerotiorum. Therefore, clear pathogen-host specific resistance for white mold disease in common beans has not been validated here or in elsewhere yet. Indeed this kind of resistance probably does not exist for $P$. vulgaris $\mathrm{x} S$. sclerotiorum because the fungus has low specificity and is able to infect great number of plant species (SAHARAN; MEHTA, 2008).

\section{ACKNOWLEDGMENTS}

The authors thank the institutions Research Foundation of the State of Minas Gerais (FAPEMIG), National Council of Scientific and Technological Development (CNPq) for the financial support.

RESUMO: Os objetivos deste estudo foram verificar a resistência de linhagens de feijoeiro derivadas de diferentes ciclos de seleção recorrente para resistência ao mofo branco e identificar aquelas mais estáveis quando inoculadas com diferentes isolados; comparar a agressividade de diferentes isolados de Sclerotinia sclerotiorum e verificar se há interação isolados x linhagens. Quinze linhagens de feijoeiro comum foram avaliadas, doze derivadas de seleção recorrente para mofo branco, uma fonte de resistência não adaptada (Cornell 605), uma moderadamente resistente e adaptada (VC-16) e uma suscetível ao mofo branco (Corujinha). Dez isolados foram utilizados para inocular as linhagens de feijoeiro através do straw test. Foram realizados dez experimentos, um para cada isolado. O delineamento experimental utilizado foi o de blocos casualizados, com três repetições. Em cada parcela, cinco plantas foram inoculadas em dois ramos principais, portanto, os dados da parcela foram a média de dez avaliações utilizando uma escala de nove notas. A análise dialélica foi utilizada para estimar a capacidade geral de reação (linhagens) e capacidade geral de agressividade (isolados) para medir, respectivamente, a resistência das linhagens e a agressividade dos isolados. A análise GGE biplot foi utilizada para agrupar as linhagens baseado em seus alelos de resistência e identificar as mais estáveis aos isolados. A resistência das linhagens P4 e P10 foi semelhante à Cornell 605, com reação estável e grãos tipo "Carioca". Como esperado, as linhagens dos ciclos mais avançados de seleção recorrente acumularam mais alelos favoráveis que aquelas dos primeiros ciclos confirmando a eficiência da seleção. Além disso, foram identificados isolados mais agressivos, UFLA109 e UFLA 116 e interação isolados x linhagens de pequena magnitude, indicando um predomínio da resistência horizontal.

PALAVRAS-CHAVE: Phaseolus vulgaris. Resistência Fisiológica. Interação linhagens x isolados. Straw test.

\section{REFERENCES}

CARNEIRO, F. F.C; SANTOS, J. B.; LEITE, M. E.; CARVALHO, R. S. B.; LIMA, A. I. Assessment of the aggressiveness of isolates of Sclerotinia sclerotiorum and of the resistance of common beans. Annual Report of the Bean Improvement Cooperative, East Lansing, v. 54, p. 132-133, 2011.

http://bic.css.msu.edu/_pdf/Reports/BIC_2011_volume_54.pdf 
CRUZ, C. D. GENES - a software package for analysis in experimental statistics and quantitative genetics. Acta Scientiarum, Maringá, v. 35, p. 271-276, 2013. http://dx.doi.org/10.4025/actasciagron.v35i3.21251

GONÇALVES, P. R. C.; SANTOS, J. B. Physiological resistance of common bean cultivars and Lines to white mold based on oxalic acid reaction. Annual Report of the Bean Improvement Cooperative, East Lansing, v. 53, p. 236-237, 2010. http://bic.css.msu.edu/_pdf/Reports/BIC_2010_Annual_Report.pdf

GRIFFITHS, P. D. Release of Cornell 601- 606: common bean breeding lines with resistance to white mold. HortScience, v. 44, n. 2, p. 463-465, 2009. http://hortsci.ashspublications.org/content/44/2/463.full.pdf

JOHAL, G. S.; GRAY, J.; GRUIS, D.; BRIGGS, S. P. Convergent insights into mechanisms determining disease and resistance response in plant-fungal interactions. Canadian Journal Botany, v. 73, p. 468-474, 1995. http://dx.doi.org/10.1139/b95-284

KOGA, L. J.; BOWEN, C. R.; GODOY, C. V.; OLIVEIRA, M. C. N; HARTMAN, G. L. Mycelial compatibility and aggressiveness of Sclerotiniasclerotiorum isolates from Brazil and the United States. Pesquisa agropecuária brasileira, Brasília, v. 49, n. 4 p. 265-272, 2014. http://dx.doi.org/10.1590/S0100204X2014000400004

KULL, L. S.; PEDERSON, W. L.; PALMQUIST, D.; HARTMAN, G. L. Mycelial compatibility groupings and virulence of Sclerotinia sclerotiorum. Plant Disease, Tampa, v. 88, p. 325-332, 2004.

http://dx.doi.org/10.1094/PDIS.2004.88.4.325

LARA, L. A. C.; SANTOS, J. B.; VELOSO, J. S.; BALESTRE, M.; ALVES, F. C.; LEITE, M. E. Identification of QTLs for Resistance to Sclerotinia sclerotiorum in Carioca Common Bean by the Moving Away Method. ISRN Molecular Biology, Madison, v. 201, p. 1-7, 2014. s http://dx.doi.org/10.1155/2014/828102

LARA, L. A. C.; SANTOS, J. B.; BALESTRE, M.; LIMA, I. A.; PAMPLONA, A. K. A.; VELOSO, J. S.; SILVA, P. H. Identification of QTLs of resistance to white mold in common bean from multiple markers by using Bayesian analysis. Genetics and molecular research, Ribeirão Preto, v. 14, n. 1, p. 1124-1135, 2014. http://dx.doi.org/10.4238/2015.February.6.16

LEHNER, M. S.; PAULA JÚNIOR, T. J.; LIMA, R. C.; VIEIRA, R. F.; SOARES, B. A.; CRUZ NETO, L. B. M.; CARNEIRO, J. E. S. Mycelial compatibility grouping and aggressiveness of Sclerotinia sclerotiorum isolates from four states of Brazil. Annual Report of the Bean Improvement Cooperative, East Lansing, v. 56, p. 53-54, 2013. http://bic.css.msu.edu/_pdf/Reports/BIC_2013_Annual_Report.pdf

LEHNER, M. S.; PAULA JÚNIOR, T.J .; HORA JÚNIOR, B. T.; TEIXEIRA, H; VIEIRA, R. F.; CARNEIRO, J. E. S; MIZUBITI, E. S. G. Low genetic variability in Sclerotinia sclerotiorum populations from common bean fields of Minas Gerais State, Brazil, at regional, local and micro scales. Plant Pathology, Hoboken, v. 64, p. 921-931. 2015. http://dx.doi.org/10.1111/ppa.12322

LEHNER, M. S.; LIMA, R. C.; CARNEIRO, J. E. S; PAULA JÚNIOR, T. J.; VIEIRA, R.F.; MIZUBITI, E. S. G. Similar aggressiveness of phenotypically and genotypically distinct isolates of Sclerotinia sclerotiorum. Plant Disease, Tampa, v. 100, p. 360-366, 2016a. http://dx.doi.org/10.1094/PDIS-04-15-0400-RE

LEHNER, M. S.; PAULA JÚNIOR, T. J.; VIEIRA, R. F.; LIMA, R. C.; SOARES, B. A.; SILVA, R. A. Reaction of sources of resistance to white mold to microsatellite haplotypes of Sclerotinia sclerotiorum. Scientia Agricola, Piracicaba, v. 73, p. 184-188, 2016b. http://dx.doi.org/10.1590/0103-90162015-0085 
LEITE, M. E.; SANTOS, J. B.; RIBEIRO JUNIOR, P. M.; SOUZA, D. A.; LARA, L. A. C.; RESENDE M. L. V. Biochemical responses associated with common bean defense against Sclerotinia sclerotiorum. European Journal of plant pathology, Dordrecht, v. 138, n. 2, p. 391-404, 2014. http://dx.doi.org/10.1007/s10658-0130341-1

LEITE, M. E.; DIAS, J. A.; SOUZA, D. A.; ALVES, F. C.; PINHEIRO, L. R.; SANTOS, J. B. Increasing the resistance of common bean to white mold through recurrent selection. Scientia Agricola, Piracicaba, v. 73, n. 1, p. 71-78, 2016. http://dx.doi.org/10.1590/0103-9016-2015-0084

LYON, M. E.; DICKSON, M. H.; HUNTER, J. E. Recurrent selection for resistance to white mold in Phaseolus species. Journal of the American Society for Horticultural Science, v. 112, n. 1, p. 149-152, 1987.

MALVÁREZ, G.; CARONE, I.; GRÜNWALD, N. J.; SUBBARAO, K. V.; SCHAFER, M.; KOHN, L. M. New populations of Sclerotinia sclerotiorum from lettuce in California and peas and lentils in Washington. Phytopathology, St Paul, v. 97, n. 4, p. 470-483, 2007. http://dx.doi.org/10.1094/PHYTO-97-4-0470

MELO, L. C.; SANTOS, J. B. Identification of resistant genotypes considering polygenic systems in hostpathogen interaction. Genetic and Molecular Biology, São Paulo, v. 22, n. 4, p. 601-608, 1999. http://dx.doi.org/10.1590/S1415-47571999000400022

MIKLAS, P. N.; PORTER, L. D.; KELLY, J. D.; MYERS, J. R. Characterization of white mold disease avoidance in common bean. European Journal of plant pathology, Dordrecht , v. 135, p. 525-543, 2013. http://dx.doi.org/10.1007/s10658-012-0153-8

OTTO-HANSON, L.; STEADMAN, J. R.; HIGGINS, R.; ESKRIDGE, K. M. Variation in Sclerotinia sclerotiorum bean isolates from multisite resistance screening locations. Plant Disease, Tampa, v. 95, n. 11, p. 1370-1377, 2011. http://dx.doi.org/10.1094/PDIS-11-10-0865

PASCUAL, A.; CAMPA, A.; PÉREZ-VEGA, E.; GIRALDEZ, R.; MIKLAS, P. N.; FERREIRA, J. J. Screening common bean for resistance to four Sclerotinia sclerotiorum isolates collected in northern Spain. Plant Disease, Tampa, v. 94, n. 7, p. 885-890, 2010. http://dx.doi.org/10.1094/PDIS-94-7-0885

PARLEVLIET, J. E. Stabilizing selection in crop pathosystems: An empty concept or a reality? Euphytica, Dordrecht, v. 30, p. 259-269, 1981. http://dx.doi.org/10.1007/BF00033986

PÉREZ-VEGA, E.; PASCUAL, A.; CAMPA, A.; GIRALDEZ, R.; MIKLAS, P. N.; FERREIRA, J. J. Mapping QTL conferring partial physiological resistance to white mold in the common bean RIL population Xana/Cornell 49242. Molecular Breeding, Dordrecht, v. 29, p. 31-41, 2012. http://dx.doi.org/10.1007/s11032010-9522-1

SAHARAN, G. S.; MEHTA, N. Sclerotinia Diseases of Crop Plants: Biology, Ecology and Disease Management. LXII. Springer-Verlag GmbH, Heidelberg, German, 2008, 486p.

SCHWARTZ, H. F.; SINGH, S. P. Breeding common bean for resistance to diseases: a review. Crop Science, Madison, v. 53, p. 1832-1844, 2013. http://dx.doi.org/10.2135/cropsci2013.02.0081

SCOTT, A. J.; KNOTT, M. Cluster analysis method for grouping means in the analysis of variance. Biometrics, p. 30, n. 3, p. 507-512, 1974. http://www.jstor.org/stable/2529204

SILVA, P. H. da; SANTOS, J. B. dos; LIMA, I. A.; LARA, L. A. C.; ALVES, F. C. Reaction of common bean lines and aggressiveness of Sclerotinia sclerotiorum isolates. Genetic and Molecular research, Ribeirão Preto, v. 13, n. 4, p. 9138-9151, 2014. http://dx.doi.org/10.4238/2014.November.7.11 
TERÁN, H.; SINGH, P. S. One cycle of recurrent selection for physiological resistance to white mold in dry bean. Annual Report of the Bean Improvement Cooperative, East Lansing p. 51, p. 42-43, 2008. http://bic.css.msu.edu/_pdf/Reports/BIC_2008_Annual_Report.pdf

TERÁN, H.; SINGH, P.S. Gamete selection for improving physiological resistance to white mold in common bean. Euphytica, Dordrecht, v.167, n.3, p. 271-280, 2009. http://dx.doi.org/10.1007/s10681-009-9885-8

TERÁN, H.; SINGH, P. S. Recurrent selection for physiological resistance to white mold in dry bean. Plant Breeding, v. 129, n. 3, p. 327-333, 2010. http://dx.doi.org/10.1111/j.1439-0523.2009.01679.x

YAN, W.; FALK, D. E. Biplot analysis of host-by-pathogen interaction. Plant Disease, Tampa, v. 86, n. 12, p. 1396-1401, 2002. http://dx.doi.org/10.1094/PDIS.2002.86.12.1396

YAN, W.; KANG, M. S. GGE Biplot Analysis - A Graphical Tool for Breeders, Geneticists and Agronomists. CRC Press LLC, New York, NY, USA, 2003, 288 p.

YANG, B.; SRIVASTAVA, S.; DEYHOLOS, M. K.; KAV, N. N. V. Transcriptional profiling of canola (Brassica napus L.) responses to the fungal pathogen Sclerotinia Sclerotiorum. Plant Science, v. 173, p. 156171, 2007. https://doi.org/10.1016/j.plantsci.2007.04.012 